\title{
Silibinin Inhibits the Hepatocellular Carcinoma in NDEA-Induced Rodent Carcinogenesis Model: An Evaluation through Biochemical and Bio-Structural Parameters
}

\author{
Abhishek Kumar', Priyashree Sunita ${ }^{2,3}$ and Shakti P Pattanayak ${ }^{1,3 *}$ \\ ${ }^{1}$ Division of Pharmacology, Department of Pharmaceutical Technology and Sciences, Birla Institute of Technology, Mesra, Ranchi- 835215, India \\ ${ }^{2}$ Government Pharmacy Institute, Department of Health Education and Family Welfare, Govt. of Jharkhand, Bariatu-834009, Ranchi, Jharkhand, India \\ ${ }^{3}$ Department of Pharmacology, School of Pharmacy - Faculty of Medicine, The Hebrew University of Jerusalem, Jerusalem- 91120 , Israel
}

\begin{abstract}
The present study was aimed to investigate the chemopreventive potential of Silibinin (SIB) against $\mathrm{N}$-nitrosodiethylamine (NDEA)-induced hepatocellular carcinoma (HCC) in wistar rats. Thirty experimental animals were subjected to partial hepatectomy $(\mathrm{PH})$ and after 24 hours of stabilization period a single dose of NDEA (100 mg/kg b.w., i.p) was administered to each animal followed by $\mathrm{CCl}_{4}(1 \mathrm{ml} / \mathrm{kg}$ b.w., s.c.). The effect of SIB $(25$ and $50 \mathrm{mg} / \mathrm{kg} / \mathrm{day}$, i.p.) on NDEA-induced HCC was determined after 2 weeks of treatment $\left(6^{\text {th }}\right.$ to $8^{\text {th }}$ week after $\mathrm{PH}$, in the promotional stage of tumor development). NDEA treatment to rats resulted in significant decrease in body weight and increase in liver weight along with levels of transaminases, $y$-glutamyl transferase, lipoprotein, glycoproteins. Hepatic and serum malondialdehyde content, enzymatic and non-enzymatic antioxidant levels were also altered in $\mathrm{HCC}$ bearing animals without treatment. Bio-structural components (such as amide bands of proteins, symmetric phosphate stretching of nucleic acids, methylene chains in membrane lipids, methyl to methylene ratio of carbohydrates and proteins etc.) were marked in NDEA-treated groups of animals by analysing changes in the position and intensities of the peaks in Fourier transform infrared spectroscopy (FTIR). Immunohistochemical staining of Ki67 and histopathological analysis were also carried out in order to support the study. SIB treatment could attenuate NDEA-induced hepatocarcinogenesis by improving the biochemical and bio-structural changes of the hepatic tissue near normal levels in a dose dependent manner. Taken together, this study reveals that SIB may have potential as a multi-functional drug candidate for cancer therapy.
\end{abstract}

Keywords: Liver cancer; NDEA; Silibinin; Biochemical; Biostructural; FTIR

\section{Introduction}

Liver cancer is one of the most common malignancies worldwide, especially in Asia and Africa [1]. Hepatocellular carcinoma (HCC) accounts for about $80-90 \%$ of all cancers and ranks the fifth most common and the third most deadly cancer worldwide [2]. Major risk factors for liver cancer include hepatitis viral infection, food additives, alcohol, aflatoxins, industrial toxic chemicals air and water pollutants, etc. [3].

$\mathrm{N}$-nitrosodiethylamine (NDEA), is a well-known potent hepatocarcinogenic agent present in tobacco smoke, water, cured and fried meals, cheddar cheese, agricultural chemicals, cosmetics and pharmaceutical products [4]. It is an important environmental carcinogen produces reproducible tumor in the liver [5]. Administration of NDEA has been reported to generate lipid peroxidation and activate oxygen species during hepatocarcinogenesis [6]. Oxidative stress has recently been suggested to participate in both metabolism and carcinogenic actions of nitrosamine. Liver tumor promotion in rodents has been characterized most extensively in the rat model utilizing initiation with a nitrosamine, partial hepatectomy $(\mathrm{PH})$, and subsequent promotion with polychlorinated aromatic hydrocarbons [7]. The possibility was raised that the tumor yield in the liver would be increased, if NDEA were given in the period of regeneration that followed a necrotizing dose of a hepatotoxin like $\mathrm{CCL}_{4}$ that was not full carcinogen by itself [8]. Taken together the use of NDEA for HCC animal model development is a potential tool which mimics the HCC in clinical findings.

Recent approach of chemoprevention serves as an attractive alternative to control malignancy. Flavonoids have been shown to act as scavengers of various oxidizing species, inhibit the growth of various cancer cell lines in vitro, and reduce tumor development in experimental animals $[9,10]$. Milk thistle (Silybum marianum) is the most ancient and extensively used medicinal plant for its beneficial effects on liver and other organs [11]. Silymarin, an extract isolated from its fruits and seeds, is known to provide a wide range of hepatoprotective effects, especially against diseases like hepatitis, cirrhosis and jaundice [12]. Marketed as Legalon or Flavobion, silymarin has been successfully applied in the therapy of various liver diseases. Moreover, highly efficient antitumour activities were also reported for Silymarin $[13,14]$. One of the most active constituents is Silibinin (SIB) $[(2 R, 3 R)$ 3,5,7-trihydroxy-2-[(2R*,3R*)-3-(4-hydroxy-3-methoxyphenyl)2-hydroxymethyl-1,4-benzodioxane-6-yl]-4-chromanone], which is composed of flavanone-3-ol and 1,4-benzodioxane ring systems (Figure 1). Silibinin, is consumed widely as a dietary supplement and it displays a remarkable spectrum of pharmacological activities like antioxidant, hepatoprotective, anti-inflammatory, antibacterial, antiallergic, antimutagenic, antiviral, antineoplastic, antithrombotic

*Corresponding author: Shakti P. Pattanayak, Department of Pharmacology, Schoo of Pharmacy - Faculty of Medicine, The Hebrew University of Jerusalem, Jerusalem91120, Israel Tel: +972-58-6243563/67; E-mail: sppattanayak@bitmesra.ac.in; shakti.pattanayak@mail.huji.ac.i

Received April 15, 2015; Accepted July 13, 2015; Published July 16, 2015

Citation: Kumar A, Sunita P, Pattanayak SP (2015) Silibinin Inhibits the Hepatocellular Carcinoma in NDEA-Induced Rodent Carcinogenesis Model: An Evaluation through Biochemical and Bio-Structural Parameters. J Cancer Sci Ther 7: 207-216. doi:10.4172/1948-5956.1000352

Copyright: $\odot 2015$ Kumar A, et al. This is an open-access article distributed under the terms of the Creative Commons Attribution License, which permits unrestricted use, distribution, and reproduction in any medium, provided the original author and source are credited. 
<smiles>COc1cc([C@H]2Oc3cc([C@@H]4Oc5cc(O)cc(O)c5C(=O)[C@H](O)C4CO)ccc3OC2CO)ccc1O</smiles>

Figure 1: Structure of Silibinin (SIB), Molecular weight: $482.44 \mathrm{~g} / \mathrm{mol}$, Formula: $\mathrm{C}_{25} \mathrm{H}_{22} \mathrm{O}_{10}$

and vasodilatory actions $[15,16]$, affecting basic cell functions such as proliferation, differentiation and apoptosis. It possesses anticancer effect on human hepatocellular carcinoma cells [17] and also it produced antitumor efficacy in an orthotopic drafting of Hep-55.1C cells into the liver of C57BL/6J mice [18]. Based on these claim, we for the first time tried to evaluate the effect of SIB on NDEA-induced hepatocellular carcinogenesis model which represents all stages of carciniogenesis in vivo (Figure 2).

\section{Materials and Methods}

\section{Animals}

Wistar albino rats 50-day old were purchased from National Institute of Nutrition, Hyderabad, India and used for the study. Animals were maintained on standard pelleted diet and water adlibitum. Experiments were approved by the Animal Ethics Committees of Department of Pharmaceutical Technology and Sciences, Birla Institute of Technology University, India (621/02/ac/CPCSEA) and strictly performed according to the NIH and CPCSEA, India guidelines for the care and use of laboratory animals.

\section{Chemicals}

N-Nitrosodiethylamine was obtained from the Sigma Aldrich, USA. KBr (I.R. Grade), Silibinin (M.W.: $482.44 \mathrm{~g} / \mathrm{mol}$ ) and other fine chemicals were purchased from the Sigma Aldrich, USA. Other chemicals and reagents in the study are of highest purity and standard which are commercially available.

\section{Tumor induction and experimental design}

HCC was induced by NDEA using the induction techniques given by Yadav et al. [5], Pound et al. [8] with some modifications. Briefly, $\mathrm{PH}$ was done to the animals. After 24 hours of stabilization a single dose of NDEA (100 mg/kg b.w., i.p) was administered to the animals. Phenobarbital sodium (PB, $0.05 \% \mathrm{w} / \mathrm{v}, \mathrm{P}$.O.) was given after $\mathrm{PH}$, up to 4 weeks in drinking water. $\mathrm{CCl}_{4}(1 \mathrm{ml} / \mathrm{kg}$ b.w., s.c.) was administered twice a week from $1^{\text {st }}$ week to $2^{\text {nd }}$ week.

Tumor yield and size were stabilized after 6 weeks with the initiation of NDEA. The administration of SIB was done after 6 weeks of NDEAtreatment and continued up to 8 weeks (in the promotional stage of tumor development). Five experiimental groups with six animals in each group were set up in this study as follows:

Group I: Animals with no treatment

Group II: PH was performed to the animals and received only $0.5 \%$ CMC (Vehicle)

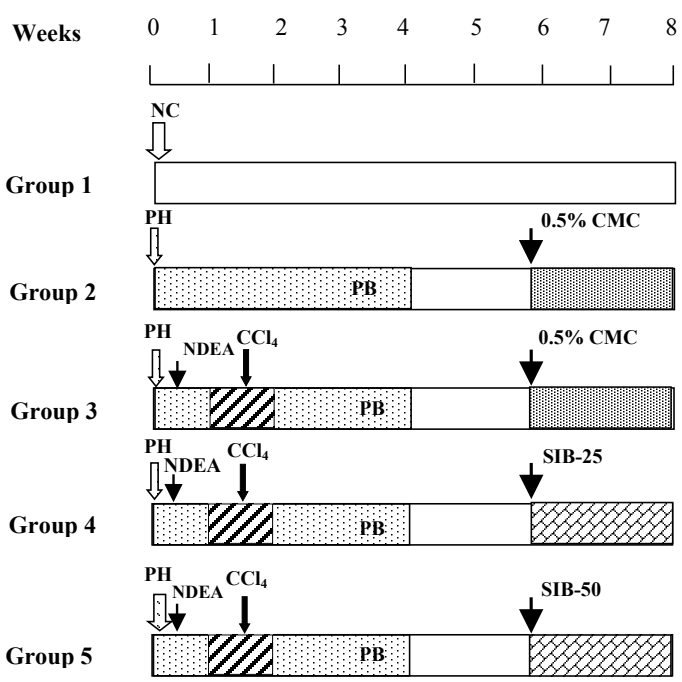

Figure 2: Experimental design for the study. $\mathrm{PH}$ - partial hepatectomy; SIB-25, 50 - Silibinin 25 and $50 \mathrm{mg} / \mathrm{kg} / \mathrm{day}$; Cis - Cisplatin; 0.5\% CMC $0.5 \%$ carboxymethyl cellulose; PB - Phenobarbital sodium.

Group III: HCC induced with NDEA (200 mg/kg b.w., i.p.) as described (after $24 \mathrm{~h}$ stabilization of $\mathrm{PH}$ ) and received only $0.5 \% \mathrm{CMC}$ for the treatment period

Group IV: Animals with HCC were treated with SIB-25 (after 6 weeks)

Group V: Animals with HCC were treated with SIB-50 (after 6 weeks)

The animals in each group were weighted each week and the changes in the body weight were recorded. All the animals were starved overnight and sacrificed by cervical decapitation after the completion of 8th week.

\section{Macroscopical documentation of tumor burden and sample preparation}

After decapitation of the animals in each group, the livers were isolated and cleaned properly using phosphate buffer saline (PBS), weighted and observed morphologically for: foci, lesions and tumors. Blood was collected; the plasma and serum were separated by centrifugation. Liver specimens were cleared for surrounding fat, weighed and cut into small pieces. $1 \mathrm{~g}$ of tissue sample was isolated from liver and freeze dried for infrared spectroscopy sampling. The other part of the liver was washed with ice cold normal phosphate buffer saline (PBS), pH 7.2 and cut into small pieces with a heavy duty blade. Tissues were homogenized by glass homogenizer tube in cold PBS, centrifuged at 20,000 rpm for $10 \mathrm{~min}$. The tissue homogenate and serum were used for the estimation of biochemical parameters.

\section{Biochemical estimations}

Aspartate dehydrogenase (AST) and alanine transaminase (ALT) were estimated in serum and homogenate by the method of King, 1965 with some modifications [19,20]. Alkaline phosphatase (ALP) was estimated according to the modified method of Belfield and Goldberg et al. [21] and gamma glutamyl transferase (GGT) by the standard method in both serum and homogenate as well [22]. Lipid peroxidation (LPO) was measured by the method of Ohkawa et al. [23]. LPO was expressed as nanomoles of malondialdehyde (MDA) formed by using 
Citation: Kumar A, Sunita P, Pattanayak SP (2015) Silibinin Inhibits the Hepatocellular Carcinoma in NDEA-Induced Rodent Carcinogenesis Model: An Evaluation through Biochemical and Bio-Structural Parameters. J Cancer Sci Ther 7: 207-216. doi:10.4172/1948-5956.1000352

an extinction coefficient of $0.152 \mathrm{mM}^{-1} \mathrm{~cm}^{-1}$ formed per milligram of protein. The protein content was estimated by the method of Lowry et al. [24]. Superoxide dismutase (SOD) activity was assessed by the nitroblue tetrazolium reduction method by Flohe and Otting et al. [25]. Catalase (CAT) activity was assayed by the method of Sinha [26] and ascorbic acid and $\alpha$-tocopherol were also accessed [20]. Oxidation of glutathione by the enzyme was measured spectrophotometrically at $420 \mathrm{~nm}$. The activity of GPx was expressed as micromoles glutathione oxidized per minute per milligram protein by Rotruck et al. [27]. Reduced glutathione (GSH), Glutathione reductase (GR) was estimated by the method of Moron et al. and glutathione- S- transferase (GST) [28].

The lipids in plasma was extracted and quantified by the method of Folch et al. [29]. Triglyceride was estimated using the method of Rice et al. [30], which is based on the method of Van Handle et al. [31]. Total cholesterol was estimated using the method of Parekh and Jung et al. [32]. Plasma lipoproteins were fractionated by dual precipitation technique of Sujatha and Sachdanandam et al. [33]. Addition of heparin-magnesium to plasma, precipitated very low-density lipoproteins (VLDL-c), low-density lipoproteins (LDL-c), and highdensity lipoproteins (HDL-c), which were left in the supernatant, and subsequently, the content was measured in the fraction. The protein bound hexose, protein bound hexosamine and protein bound sialic acid was estimated from the collected serum samples by the method of Nandave et al. [34].

\section{Histopathological and immunohistochemical studies}

For histopathological examination, liver tissues specimens from all groups were fixed in 10\% neutral-buffered formalin. The histopathology of the tissue samples with Hematoxylin and eosin staining were carried out by the modified method of Pattanayak et al. [35]. To the paraffin sections of the liver tissue, Ki67 immunolabeling was performed to assess cell proliferation [36], using a mouse monoclonal antibody (Thermo Scientific, USA), and a three-step immunoperoxidase method.

\section{FT-IR spectroscopic analysis}

The FT-IR spectra in the $4000-400 \mathrm{~cm}^{-1}$ region were recorded with a Schimatzu 8400S FT-IR Spectrometer equipped with an attenuated reflectance detector (ATR) detector. FTIR analysis was done according to the method of Palaniappan et al. [37] with some modifications. In brief, $3 \mathrm{mg}$ lyophilized sample was triturated with $100 \mathrm{mg}$ IR grade $\mathrm{KBr}$ and pelleted for standard FT-IR analysis. The spectrometer was continuously purged with dry nitrogen to eliminate atmospheric water vapor and carbon dioxide. To improve the signal to noise ratio for each spectrum, 60 scans with a spectral resolution of $\pm 4 \mathrm{~cm}^{-1}$ were averaged. Background spectra, which were collected under identical conditions, were subtracted from the sample spectra automatically. The frequencies for all sharp bands were accurate to $0.001 \mathrm{~cm}^{-1}$. To eliminate the differences due to the non-uniformity of thickness of sample and the varying of intensity of light source, all spectra were subsequently calibrated. The frequencies for all sharp bands were determined accurately from the original base line-corrected spectra belonging to the corresponding four groups. Each observation was confirmed by taking at least three replicates. The sample was then weighed to get the quantitative data. Therefore, it was possible to directly correlate the intensities of absorption bands to the concentration of the functional group. The spectra were analyzed using Schimatzu IRsolution software.

\section{Statistical analysis}

Pharmacological data were analyzed by one-way analysis of variance followed by Bonferroni's multiple comparison tests with equal sample size. The difference was considered significant when $p$ value $<0.05$. All the values were expressed as mean \pm standard error mean (SEM).

\section{Results}

\section{SIB ameliorated the alteration in body weight and liver weight in NDEA-induced liver cancer}

NDEA treatment caused significant difference in body weight (b.w.) as compared with normal control and $\mathrm{PH}$-control groups. SIB treatment in NDEA treated animals showed significant increase $(\mathrm{p}<0.001)$ in b.w. with respect to induced control in both treatment groups (Figure 3). NDEA treatment caused highly significant $(\mathrm{p}<0.001)$ increase in liver weight. SIB $(25 \mathrm{mg} / \mathrm{kg} /$ day $)$ administration caused significant $(\mathrm{p}<0.05)$ decrease and higher dose (SIB-50 mg/kg/day) caused complete normalization of liver weight (Figure 4). The representative images of the liver of all groups of rats are depicted in Figure 5.

\section{Antioxidant status and biochemical changes in HCC-rats were attenuated by SIB}

NDEA treated rats showed significant $(\mathrm{p}<0.01)$ increase in the AST, ALT, ALP and $\gamma$-GT levels in the serum (Figure 6) and tissue homogenate (Figure 7) as compared to the control group animals. SIB treatment produced significant $(\mathrm{p}<0.05)$ decrease in the liver marker levels in both treatment groups of animals. High dose treated animals showed more significant $(\mathrm{p}<0.01)$ decrease in the transaminase and $\gamma$-GT enzymes with respect to induced control group.

Table 1 represents the plasma lipoprotein cholesterol profile such as HDL-c, LDL-c, and VLDL-c levels of all groups along with TC and TG. The levels of HDL-c significantly $(\mathrm{p}<0.001)$ decreased in group III animals as compared with those in group I. The levels of VLDL-c and LDL-c significantly $(\mathrm{p}<0.001)$ increased in the same manner. However, significantly $(\mathrm{p}<0.05)$ decreased levels of VLDL-c, LDL-c and increased levels of HDL-c were observed in groups IV, and V animals as compared with those in group III animals. The TC and TG levels were also found

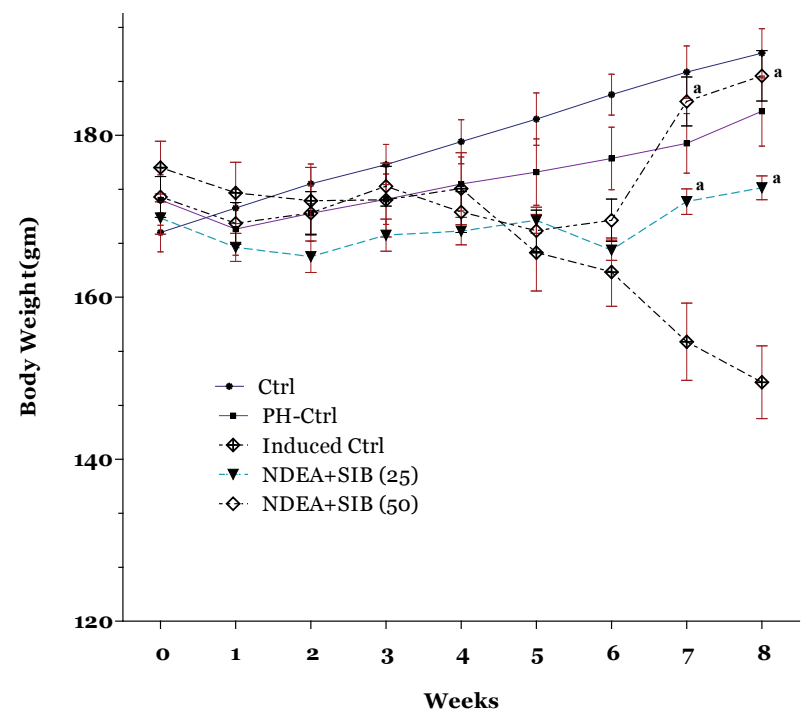

Figure 3: Mean body weight (gms) of normal and different groups of animals for 8 weeks of experimental period. Comparisons: NDEA+SIB (25) and NDEA+SIB (50) groups of animals compared with Induced control (induced-ctrl). Values are expressed as Mean \pm standard deviations. Significant: $a<0.01$. 


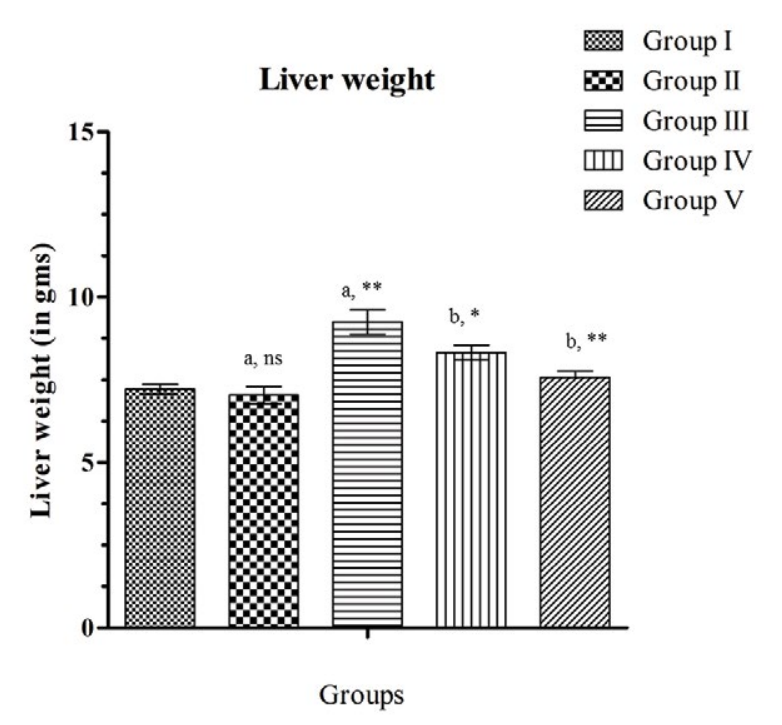

Figure 4: Mean liver weight (gm) of normal and different treatment groups after 8 weeks. Values are expressed as mean \pm SEM for Six animals. Group I: Normal control; Group II: PH-control; Group III: NDEA; Group IV: NDEA+SIB (25 mg/kg/day); Group V: NDEA+SIB (50 mg/kg/day) Comparisons: $a=$ groups II and III with group I; $b=$ group IV and V with group III. Significant: ${ }^{\text {ns }} p>0.05 ;{ }^{*} p<0.05 ;{ }^{* *} p<0.01 ;{ }^{* * *} p<0.001$.

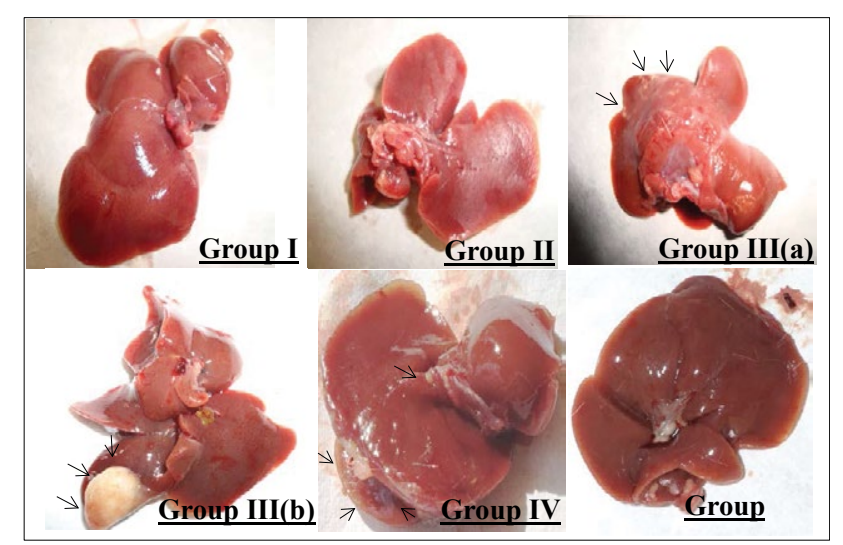

Figure 5: Effect of Silibinin (SIB) on liver marker enzymes in serum all tested group of animals. Values are expressed as mean \pm SEM for Six animals. Group I: Normal control; Group II: PH-control; Group III: NDEA; Group IV: NDEA+SIB (25 mg/kg/day); Group V: NDEA+SIB (50 mg/kg/day). Comparisons: $a=$ groups II and III with group I; $b=$ group IV and V with group III. Significant: ${ }^{\text {ns }} p>0.05 ;{ }^{*} p<0.05 ;{ }^{* *} p<0.01 ;{ }^{* * *} p<0.001$.

to be significantly increased in the Group III animals and brought back to normal levels in a dose dependent manner after the SIB treatment.

Table 2 shows activities of glycoproteins in the serum in all experimental groups. A significant $(\mathrm{P}<0.01)$ increase in activity of sialic acid, hexose and hexosamine were observed in the group III animals. After the treatment with SIB for 2 weeks, these alterations in glycoprotein levels significantly decreased in a concentration dependent manner (group IV and V) (Figure 8).

The activities antioxidants in serum and liver homogenates were depicted in Tables 3 and 4, respectively. The status of SOD, CAT, GSH, GR, GPx and GST were recorded to be significantly $(\mathrm{p}<0.001)$ increased

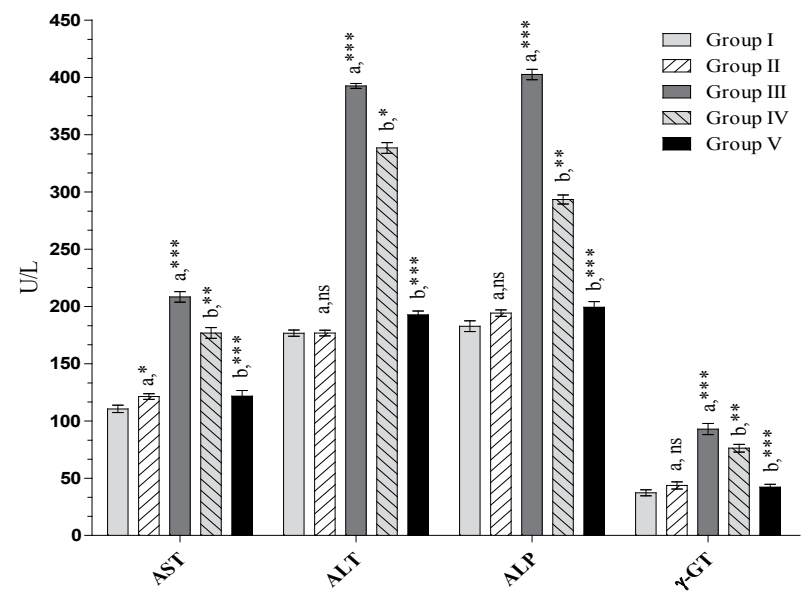

Figure 6: Effect of Silibinin (SIB) on liver marker enzymes in tissue homogenate of all tested group of animals. Values are expressed as mean \pm SEM for six animals. Group I: Normal control; Group II: PH-control; Group III: NDEA; Group IV: NDEA+SIB (25 mg/kg/day); Group V: NDEA+SIB (50 $\mathrm{mg} / \mathrm{kg} /$ day). Comparisons: $\mathrm{a}=$ groups II and III with group I; $b=$ group IV and V with group III. Significant: ${ }^{\text {ns }} p>0.05 ;{ }^{*} p<0.05 ;{ }^{* *} p<0.01 ;{ }^{* * *} p<0.001$.

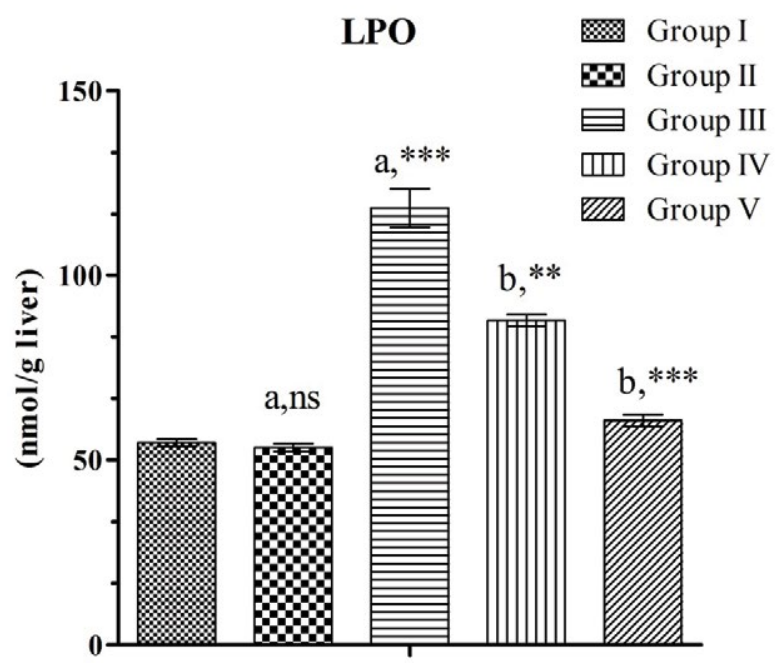

Figure 7: Effect of Silibinin (SIB) treatment on lipid peroxidation in liver homogenate tissue preparation from normal and treatment groups of animals. Values are expressed as mean \pm SEM for Six animals. Group I: Normal control; Group II: PH-control; Group III: NDEA; Group IV: NDEA+SIB $(25 \mathrm{mg} / \mathrm{kg} / \mathrm{day})$; Group V: NDEA+SIB (50 mg/kg/day). Comparisons: $\mathrm{a}=$ groups II and III with group I; b = group IV and V with group III. Significant: ${ }_{\text {ns }} p>0.05 ;{ }^{*} p<0.05 ;{ }^{* *} p<0.01 ;{ }^{* * *} p<0.001$.

in serum samples of NDEA-induced group as compared to control group I. Although the low dose SIB $(25 \mathrm{mg} / \mathrm{kg} /$ day $)$ treatment increased the antioxidant levels HCC mice, but a propound increase was observed with the high dose $(50 \mathrm{mg} / \mathrm{kg} /$ day) treatment group of animals (Table 3). The similar findings were also recorded for the enzymic and nonenzymic antioxidant levels in liver tissue homogenates of all tested groups (Table 4). The levels of lid peroxidation in only NDEA-treated animals (group III) was significantly increased $(\mathrm{p}<0.01)$ with respect to group I animals and it was brought back to almost normal levels after 14 day treatment with SIB at a dose level of $50 \mathrm{mg} / \mathrm{kg} /$ day. 


\begin{tabular}{|c|c|c|c|c|c|}
\hline Groups & Group I & Group II & Group III & Group IV & Group V \\
\hline $\mathrm{TC}(\mathrm{mg} / \mathrm{dl})$ & $8.23 \pm 0.8$ & $8.55 \pm 0.18^{a, n s}$ & $18.22 \pm 0.08^{a, * * *}$ & $14.35 \pm 0.14^{\mathrm{b}, *}$ & $9.32 \pm 0.34^{b_{*}^{* * *}}$ \\
\hline HDL-c(mg/g wet tissue) & $41.65 \pm 1.07$ & $45.24 \pm 0.52^{\mathrm{a}, \mathrm{ns}}$ & $22.95 \pm 0.45^{\mathrm{a}, * \pm+}$ & $30.08 \pm 0.80^{b, *}$ & $42.38 \pm 0.06^{b^{, *+*}}$ \\
\hline LDL-c(mg/g wet tissue) & $54.33 \pm 0.44$ & $60.50 \pm 0.41$ a, ns & $132.28 \pm 0.15^{a, * * *}$ & $104.41 \pm 0.62^{\mathrm{b},{ }^{\star}}$ & $69.40 \pm 0.02^{\mathrm{b}, *+*}$ \\
\hline VLDL-c(mg/g wet tissue) & $18.32 \pm 0.15$ & $19.05 \pm 0.32^{\mathrm{a}, \mathrm{ns}}$ & $53.20 \pm 1.90^{a, * * *}$ & $40.12 \pm 0.14^{b, * *}$ & $21.12 \pm 0.05^{b,+* x}$ \\
\hline TG & $93.40 \pm 1.56$ & $94.88 \pm 1.01$ a, ns & $192.32 \pm 1.57^{a, * * *}$ & $156.71 \pm 1.20^{\mathrm{b},{ }^{\star}}$ & $121.67 \pm 1.34^{\mathrm{b}, *+*}$ \\
\hline
\end{tabular}

Values are expressed as mean \pm SEM for Six animals. Group I: Normal control; Group II: PH-control; Group III: NDEA; Group IV: NDEA+SIB(25mg/kg/day); Group V: $\mathrm{NDEA}+\mathrm{SIB}\left(50 \mathrm{mg} / \mathrm{kg} /\right.$ day). Comparisons: $\mathrm{a}=$ groups II and III with group I; b = group IV and V with group III. Significant: ${ }^{\mathrm{ns}} p>0.05 ;{ }^{*} p<0.05 ;{ }^{* *} p<0.01 ;{ }^{* * \star} p<0.001$.

Table 1: Effect of Silibinin (SIB) on lipoprotein levels in plasma of induced and treatment groups.

\begin{tabular}{|c|c|c|c|c|c|}
\hline Groups (mg/g) & Group I & Group II & Group III & Group IV & Group V \\
\hline Hexose & $30.0 \pm 0.65$ & $34.39 \pm 0.71^{a, *}$ & $57.32 \pm 0.56^{a,+* *}$ & $49.67 \pm 0.34^{\mathrm{b}, *}$ & $38.24 \pm 0.41^{\mathrm{b},+*+}$ \\
\hline Hexosamine & $22.16 \pm 0.39$ & $20.78 \pm 0.42^{a, n s}$ & $40.26 \pm 0.22^{a, * * *}$ & $32.63 \pm 0.61^{\mathrm{b},+*+}$ & $23.09 \pm 0.30^{\mathrm{b}, *+*}$ \\
\hline Sialic acid & $26.22 \pm 0.44$ & $26.60 \pm 0.37^{\mathrm{a}, \mathrm{ns}}$ & $45.23 \pm 0.51^{\mathrm{a},+\star * t}$ & $38.27 \pm 0.57^{b, *}$ & $31.26 \pm 0.80^{\mathrm{b}, *+*}$ \\
\hline
\end{tabular}

Values are expressed as mean \pm SEM for Six animals. Group I: Normal control; Group II: PH-control; Group III: NDEA; Group IV: NDEA+SIB (25 mg/kg/day); Group V: NDEA+SIB (50 mg/kg/day). Comparisons: a = groups II and III with group I; b = group IV and V with group III. Significant: ${ }^{n s} p>0.05 ;{ }^{*} p<0.05 ;{ }^{* *} p<0.01 ;{ }^{* \star *} p<0.001$.

Table 2: Effect of SIB on glycoprotein level in serum of induced and treatment groups of animals.

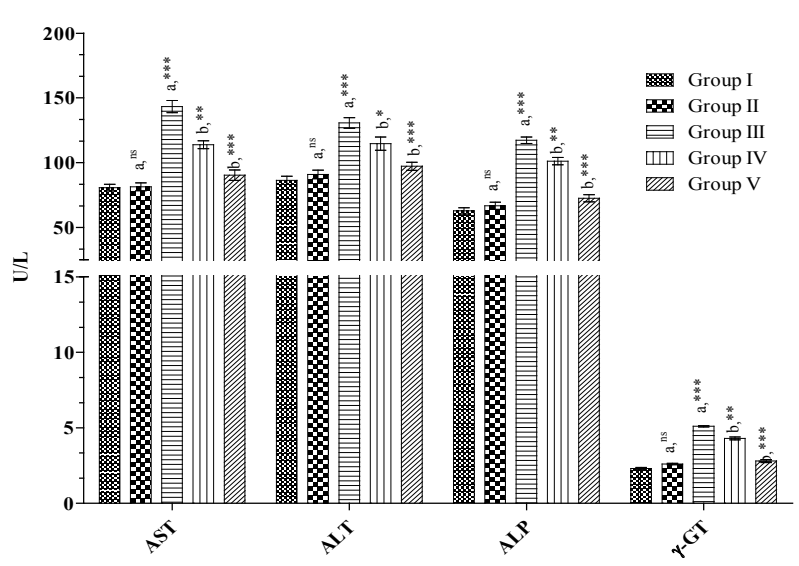

Figure 8: Photographs represent the Liver from each group of animals. Arrows indicates the foci and tumor in liver. Group I: Normal control; Group II: PH-control; Group IIIa: NDEA-induced HCC (after 3 weeks); Group IIIb: NDEA-induced HCC (at the end of the experimental period); Group IV: NDEA+SIB (25 mg/kg/day); Group V: NDEA+SIB (50 mg/kg/day).

\section{SIB-treatment customized the tissue architecture and hepatocytes proliferation in HCC}

The histopathological examination of liver sections of NDEAtreated rats showed multiple nucleoli, hyperchromatic malignant nuclei, cellular infiltration, protein and cytoplasmic leakage (Figure 9) in comparison to the $\mathrm{PH}$-control and normal control animals liver. A decrease in degenerative changes and cytoplasmic leakage was showed in SIB $(25 \mathrm{mg} / \mathrm{kg} /$ day) and SIB $(50 \mathrm{mg} / \mathrm{kg} /$ day) treated animals (Figure 9) groups. But the high dose revealed almost normal architecture comparison to the low dose treated group of animals.

The kinetics of hepatocytes proliferation was examined by Ki67immunolabeling. A high proportion of hepatocytes were Ki67-positive (brown colored in Figure 10 (NDEA)). The rate of hepatocytes proliferation in the SB-treated animals progressively decreased thereafter (Figure $10 \mathrm{NDEA}+\mathrm{SIB}$ (25), SIB (50)). At the end of followup, the rate of hepatocytes proliferation had returned to basal levels in high dose treated groups of animals.

Changes in the bio-structural components has been altered by SIB in HCC-bearing rats

A complete scanning of the normal as well as other treated group samples was done. The general band assignments of the FTIR spectra of liver tissue on the basis of reported literature of Wistar rat for comparison among all groups were depicted in supplemental Table 1. The FT-IR spectra for the normal and PH-control group tissues (Figure 11a) showed no difference in spectral peak positions. The spectra of NDEA-induced group was compared with normal control group (Figure $11 \mathrm{~b})$, the spectra showed many changes in the intensities and position of peaks like peaks for amide I, amide II, amide A bands, olefinic band at $3010 \mathrm{~cm}^{-1}$, peak at $1401 \mathrm{~cm}^{-1}$ and $1452 \mathrm{~cm}^{-1}$ due to methyl group of protein, peaks at $1065 \mathrm{~cm}^{-1}$ and $1088 \mathrm{~cm}^{-1}$ etc. The changes in the peak position and intensities were decreased in the spectra of SIB treated group as compared to NDEA-induced group (Figure 11c). Changes in the peak intensities of amide I and amide II bands, reappearance of olefinic band with a shift to $3007 \mathrm{~cm}^{-1}$, change in peak near $1720 \mathrm{~cm}^{-1}$ of ester group, peak near $1024 \mathrm{~cm}^{-1}$ were observed. The spectra of SIB (50 mg/kg/day) treated group was compared with NDEA-treated group (Figure 11d) were found with variations at numerous peaks such as, amide I and amide II bands, olefinic peak, amide A and B bands, band shift in peaks near $1024 \mathrm{~cm}^{-1}$. The FTIR spectra of SIB treated group have similarities with normal control group spectra.

\section{Discussion}

Rats treated with NDEA significantly reduce the body weight might be due to stress compared to control animals. The reduction in body weight of the animals in this study correlate with the decreased food intake observed during the experimental period which appeared to reduced metabolism and hepatotoxicity [38]. Liver damage caused by NDEA and $\mathrm{CCl}_{4}$ generally reflects instability of liver cell metabolism which leads to distinctive changes in the serum enzyme activities. Serum transaminases, ALP and $\gamma$-GT are representative of liver function and their increased levels are indicators of liver damage. The increase in ALT activity is repeatedly credited to hepatocellular damage and is usually accompanied by a rise in AST. Similarly, increase in ALP reflects pathological alteration in biliary flow and discharge of total bilirubin reflects a non-specific alteration in the plasma membrane integrity and/or permeability. $\gamma$-GT is an enzyme in the hepatocyte plasma membrane, its liberation into serum indicates cellular damage to liver. Hence $\gamma$-GT is considered to be one of the best indicators of liver damage [39]. After partial hepatectomy only a slight to moderate increase in serum transaminase activity was recorded specifically with AST of liver tissue preparation. In patients with hepatocellular carcinoma high preoperative levels of ALT, ALP, AST and $\gamma$-GT indicates a significantly increased risk to develop tumor recurrence after 
Citation: Kumar A, Sunita P, Pattanayak SP (2015) Silibinin Inhibits the Hepatocellular Carcinoma in NDEA-Induced Rodent Carcinogenesis Model: An Evaluation through Biochemical and Bio-Structural Parameters. J Cancer Sci Ther 7: 207-216. doi:10.4172/1948-5956.1000352

\begin{tabular}{|c|c|c|c|c|c|}
\hline Groups & Group I & Group II & Group III & Group IV & Group V \\
\hline SOD (U/min/mg protein) & $4.87 \pm 0.09$ & $4.34 \pm 0.078^{a, n s}$ & $2.09 \pm 0.068^{a, * * *}$ & $3.27 \pm 0.043^{b, * *}$ & $4.03 \pm 0.062^{b,+* t+}$ \\
\hline CAT (U/min/mg protein) & $30.54 \pm 0.53$ & $28.61 \pm 0.34$ a, ns & $18.37 \pm 0.29^{a, * *}$ & $23.42 \pm 0.54^{\mathrm{b},{ }^{\star}}$ & $27.51 \pm 0.58^{b, * * *}$ \\
\hline GPx(nmol NADPH oxidized/min/mg protein) & $91.2 \pm 0.31$ & $85.7 \pm 0.31^{\text {a, ns }}$ & $58.7 \pm 0.46^{a,+* *}$ & $64.9 \pm 1.47^{\mathrm{b}, \mathrm{ns}}$ & $82.4 \pm 0.52^{b, * * *}$ \\
\hline GST(nmol CDNB conjugate/min/mg protein) & $387.60 \pm 13.64$ & $376.50 \pm 11.3^{\mathrm{a}, \mathrm{ns}}$ & $174.20 \pm 11.7^{a, * \star *}$ & $239.5 \pm 4.8^{\mathrm{b}, * *}$ & $368.3 \pm 12.7^{b,+*+}$ \\
\hline GSH (nmol GSH/mg tissue) & $2.85 \pm 0.18$ & $2.23 \pm 0.18^{\mathrm{a}, \mathrm{ns}}$ & $1.21 \pm 0.22^{\mathrm{a}, * * *}$ & $1.68 \pm 0.46^{\mathrm{b}, \mathrm{ns}}$ & $2.35 \pm 0.21^{b, *+*}$ \\
\hline GR (nmol GR/mg tissue) & $3.20 \pm 0.44$ & $2.98 \pm 0.31^{\mathrm{a}, \mathrm{ns}}$ & $1.97 \pm 0.27^{a, *+*}$ & $2.61 \pm 0.40^{\mathrm{b}, * *}$ & $3.07 \pm 0.53^{b, * * *}$ \\
\hline
\end{tabular}

Values are expressed as mean \pm SEM for Six animals. Group I: Normal control; Group II: PH-control; Group III: NDEA; Group IV: NDEA+SIB (25 mg/kg/day); Group V: NDEA+SIB (50 mg/kg/day). Comparisons: a = groups II and III with group I; b = group IV and V with group III. Significant: ns $p>0.05 ;{ }^{\star} p<0.05 ;{ }^{\star *} p<0.01 ;{ }^{* \star \star} p<0.001$.

Table 3: Effect of Silibinin (SIB) on serum antioxidant status of NDEA-induced liver cancer rats.

\begin{tabular}{|c|c|c|c|c|c|}
\hline Groups & Group I & Group II & Group III & Group IV & Group V \\
\hline SOD(U/mg protein) & $8.62 \pm 0.32$ & $8.04 \pm 0.64$ a, ns & $4.45 \pm 0.72^{a,+* *}$ & $6.36 \pm 0.87^{b, * *}$ & $8.10 \pm 0.49^{b, * * t}$ \\
\hline CAT (U/mg protein) & $60.53 \pm 1.23$ & $58.23 \pm 1.40^{\mathrm{a}, \mathrm{ns}}$ & $39.26 \pm 1.67^{a,+* *}$ & $47.66 \pm 1.5^{\mathrm{b}, *}$ & $56.16 \pm 1.62^{\mathrm{b}, * * t}$ \\
\hline GPx(nmol NADPH oxidized/min/mg protein) & $92.45 \pm 2.32$ & $89.34 \pm 1.24$ a, ns & $43.05 \pm 2.21^{\mathrm{a}, * * *}$ & $58.15 \pm 1.13^{\mathrm{b}, *}$ & $72.34 \pm 1.15^{\mathrm{b}, * \star *}$ \\
\hline GST(nmol CDNB conjugate/min/mg protein) & $179.43 \pm 2.69$ & $181.45 \pm 5.12^{\mathrm{a}, \mathrm{ns}}$ & $92.82 \pm 1.85^{\mathrm{a}, * *}$ & $129.11 \pm 2.32^{b, *}$ & $162.18 \pm 3.15^{\mathrm{b}, * \star *}$ \\
\hline GSH (nmol GSH/mg tissue) & $1.52 \pm 0.12$ & $1.48 \pm 0.14 \mathrm{a}$, ns & $0.49 \pm 0.09^{a,+* *}$ & $0.85 \pm 0.06^{\mathrm{b}, * *}$ & $1.43 \pm 0.12^{b, * *+}$ \\
\hline Ascorbic acid & $8.82 \pm 0.13$ & $8.12 \pm 0.15^{a, *}$ & $5.23 \pm 0.19^{a, * * *}$ & $6.69 \pm 0.13^{b_{*}^{* *}}$ & $7.79 \pm 0.08^{b, * * t}$ \\
\hline a-Tocopherol & $6.14 \pm 0.19$ & $5.95 \pm 0.25^{\mathrm{a}, \mathrm{ns}}$ & $3.09 \pm 0.12^{a,+* t}$ & $4.12 \pm 0.23^{b, *}$ & $5.85 \pm 0.15^{b, * * *}$ \\
\hline
\end{tabular}

Values are expressed as mean \pm SEM for Six animals. Group I: Normal control; Group II: PH-control; Group III: NDEA; Group IV: NDEA+SIB (25 mg/kg/day); Group V: NDEA+SIB $(50 \mathrm{mg} / \mathrm{kg} / \mathrm{day})$. Comparisons: a = groups II and III with group I; b = group IV and V with group III. Significant: ${ }^{n s} p>0.05 ;{ }^{*} p<0.05 ;{ }^{* *} p<0.01 ;{ }^{* \star *} p<0.001$.

Table 4: Effect of Silibinin (SIB) treatment on liver oxidative stress indices in homogenate tissue preparation from normal and treatment groups of animals.
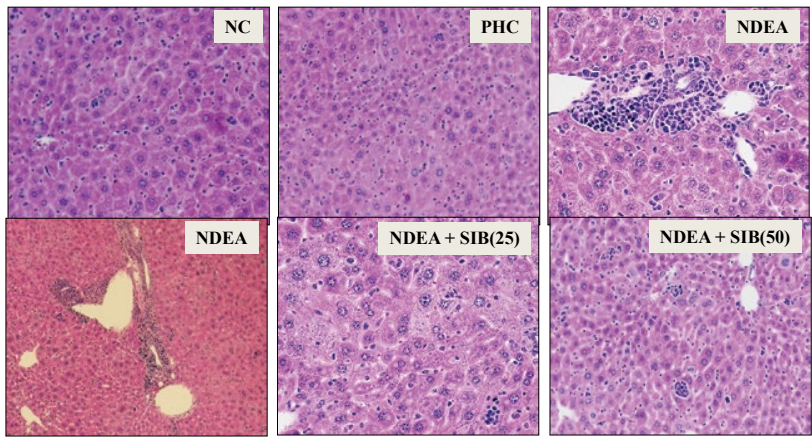

Figure 9: Histopathological observation of liver tissue in control and experimental groups of animals. NC: normal control; PHC: $\mathrm{PH}$-control; NDEA: NDEA-induced control; NDEA+SIB (25): NDEA-induced animals treated with SIB (25 mg/kg/day); NDEA+SIB (50): NDEA-induced animals treated with SIB $(50 \mathrm{mg} / \mathrm{kg} / \mathrm{day})$. The fibroadenoma of the rat hepatocytes were identified with hematoxylin and eosin stain $(\times 40)$.

hepatectomy. In the present investigation, in PH control animals, after 8 weeks all enzymes returned to almost normal level (insignificant result with normal control) and also with treatment with SIB lowered the enhanced level of activities of enzymes in HCC animals. It is suggested that SIB tends to prevent liver damage and exhibiting hepatoprotective activity, also aids in parenchyma cell regeneration in liver and thereby protecting membrane integrity by decreased enzyme leakage. This might be the reason for the restoration in the activities of the marker enzymes after administration of SIB for the specified experimental period of treatment.

The results obtained for the level of TC, c-LDL, c-VLDL, TG significantly increased and c-HDL level decreased with NDEAtreatment when compared to control group. Treatment with SIB restores these changes to near normal level. There is always a major changes found in the levels of lipoproteins along with TC and TG with patients with HCC [40]. Liver is the major site involved in the synthesis of sialic acid, hexose and hexosamine glycoproteins. The synthesized glycoproteins are made to circulate in the blood [41]. Sialic acid is an acylated derivative of neuraminic acid and exists

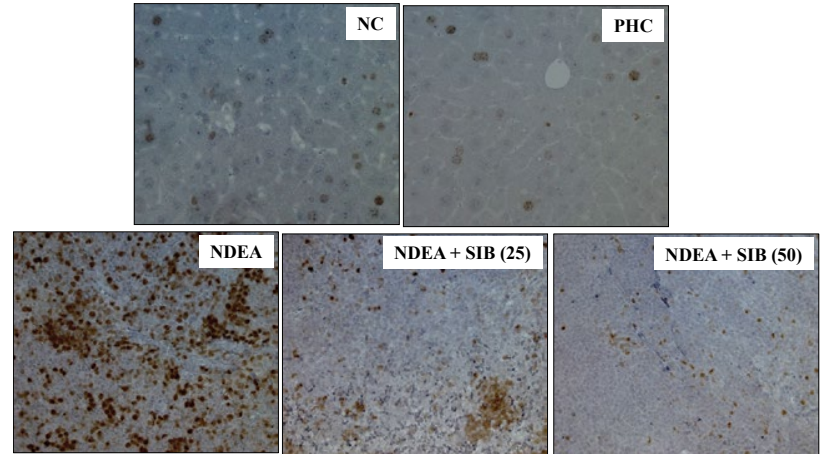

Figure 10: Cell proliferation was assessed by Ki67 immunolabeling in the liver Normal, NDEA treated and SIB treated animals. NDEA-Treated animals at the end of 8 week of induction revealed a large number of Ki67labeled hepatocytes; In normal control (NC) and $\mathrm{PH}$-control $(\mathrm{PHC})$ group of animals showed the vast majority of hepatocytes Ki67-negative; 2 weeks of treatment with SIB reduced the Ki67 positive hepatocytes in liver in a dose dependent manner. Original magnification: $\times 40$. Hepatocytes proliferation was measured as the proportion of Ki67-positive hepatocytes.

as a terminal component of the non-reducing end of carbohydrate chains of glycoprotein. Their implications in a variety of surfacerelated vital cell functions in numerous tissues including HCC are well documented. Hence, a pronounced increase in serum levels was recorded. Glycoproteins level was found to be significantly reduced after treatment with SIB (50 mg/kg/day). This study shows that SIB administration may inhibit glycoprotein synthesis in tumor cells [42].

The significant increase of hepatic GSH level in NDEA-treated rat liver is probably due to the simultaneous observed two-fold increase in the activities of $\gamma$-GT one of the principal enzymes involved in GSH formation [43]. Glutathione-S-transferases (GSTs) are a family of isoenzymes that play an important role in protecting cells from the cytotoxins and carcinogens. In addition, GSTs can bind to sequester intracellular toxins to prevent oxidative damage by an intrinsic organic peroxidase that converts toxic peroxidase to inactivated form [44]. These results indicate the ameliorative effect of SIB under cancer conditions. Moreover, GSH has a nucleophilic property that makes key 
a
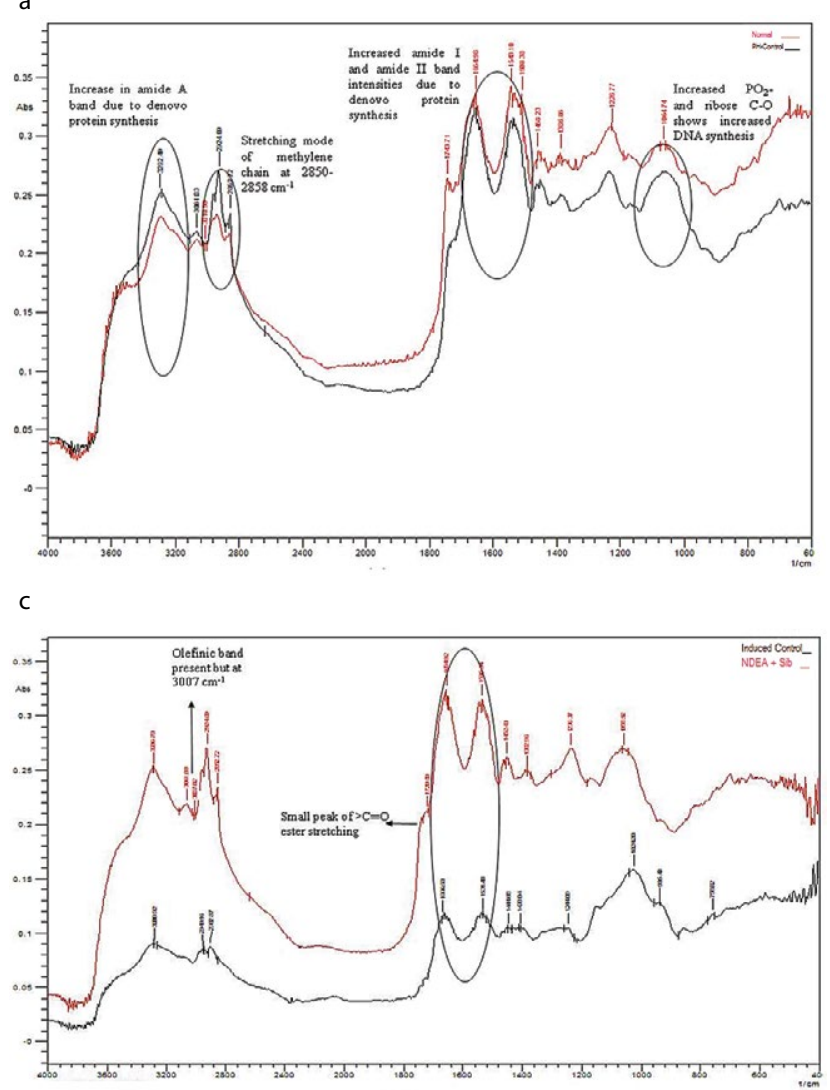

b

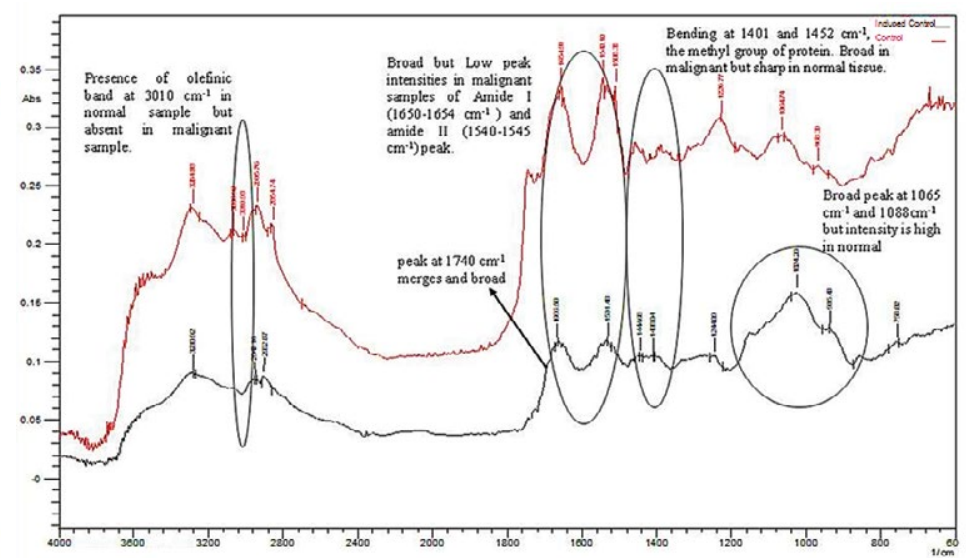

d

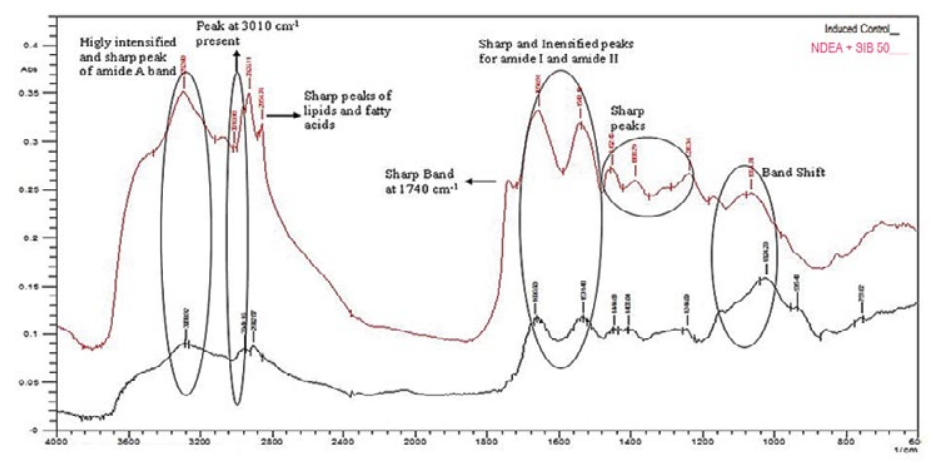

Figure 11 (a-d): Comparative FTIR spectra of different histological tissue samples, (a) Normal and PH-Control group tissue sample, (b) Normal and Induced Control, (c) Induced control and NDEA+SIB (25 mg/kg/day) treated, (d) Induced control and NDEA+SIB (50 mg/kg/day) treated groups.

role in the cellular protection from the oxidative damage. Furthermore, GSH is a cofactor of GST, which is responsible for detoxification of xenobiotics. GSH is regenerated by glutathione reductase from the oxidized glutathione. SIB has antioxidant potential which restores these enzymes. Ascorbic acid and $\alpha$-tocopherol may also account for its potential anticancer effects. Additionally, we also observed that vitamin $\mathrm{C}$ and vitamin $\mathrm{E}$ levels were significantly increased in SIB-treated cancer-bearing rats.

Oxidative damage of the vital cellular constituents such as DNA, lipids and proteins and alterations in the signal transduction pathways that control the expression of genes required to execute cell death occurs in the liver tissue due to the formation of large amount of reactive oxygen species. As the present study represented, the increased level of MDA which was a biomarker for the oxidative stress in the liver of HCC bearing animals that could be result to the excessive generation of free radicals which are produced during the metabolism of NDEA or during the process of carcinogenesis [45]. Free radical scavenging activity of SIB is confirmed by the results obtained in our findings i.e. decreased level of MDA after drug treatment. SOD was reported as one of the most important enzymes among the enzymic antioxidant defense system. It scavenges the superoxide anion to form hydrogen peroxide, hence diminishing the toxic effect caused by free radicals. In the present study, the significantly decreased level of SOD as observed in HCC induced animals which might be due to the utilization of the enzyme to scavenge $\mathrm{H}_{2} \mathrm{O}_{2}$ radicals. CAT decomposes hydrogen peroxide and protects the tissue from highly reactive hydroxyl radicals [46] and it is thought to be the first line of defense against oxidative damage induced by carcinogen. The significantly decreased level of CAT activities were recorded in NDEA-induced HCC animals as compared to normal animals may be due to the utilization of this enzyme in the removal of hydrogen peroxide radicals caused by carcinogen administration [47]. These antioxidant enzymes have been increased with the treatment of SIB at a dose level of $50 \mathrm{mg} / \mathrm{kg} /$ day for 2 weeks.

Research reports for cancer diagnosis by infrared spectroscopy have generally focused on some useful findings in molecular level (e.g. amide bands for proteins, symmetric phosphate stretching band of the phosphodiester groups of nucleic acids, methylene chains in membrane lipids, hydrogen bonding on the phosphodiester groups of nucleic acids, methyl to methylene ratio, glycogen content and hydrogen bonding of $\mathrm{C}-\mathrm{OH}$ groups in carbohydrates and protein etc.) [48]. The vibrational spectra of the protein are characterized by a set of absorption regions known as the amide region and the $\mathrm{C}-\mathrm{H}$ region. The most widely studied regions are amide I, amide II, amide III and amide A regions. Absorbance at $1650-1654 \mathrm{~cm}^{-1}$ region representing amide I region corresponding to the stretching $\mathrm{C}=\mathrm{O}$ and bending $\mathrm{C}-\mathrm{N}$ vibrational modes of the polypeptides and protein backbone and at $1540-1545 \mathrm{~cm}-1$ region assigned to the amide II band corresponding to the bending $\mathrm{N}-\mathrm{H}$ and stretching $\mathrm{C}-\mathrm{N}$ [49]. In the amide I band (1650-1655) of normal tissues (control group) (Figure 11a) the peak was found to be more intensified than that of NDEA induced cancerous tissue sample. Moreover, the difference between the peak intensity in the NDEA+SIB treated group is significant with respect to induced- 
control (Figure 11). The peak shift is insignificant. Uniformity in the peak intensity at $1650-1655 \mathrm{~cm}^{-1}$ was observed in all samples of all the groups. The changes observed are due to the variation and alteration in the protein content and its irregular composition due to alteration in cancer tissue composition and make up of specific vibrational band specially specified for amide I band. The amide I band primarily associates with a stretching motion of the $\mathrm{C}=\mathrm{O}$ group. This band is sensitive to the environment of the peptide and also depends upon overall secondary structure of protein [50]. The strong band observed at $1659 \mathrm{~cm}^{-1}$ can be assigned to $\alpha$ - helical structure [51] and amide I band is due to inplane stretching of the $\mathrm{C}=\mathrm{O}$ bond, weakly coupled with $\mathrm{C}-\mathrm{N}$ stretching and inplane $\mathrm{N}-\mathrm{H}$ bending [50]. In the region of amide II band (1540-1545 $\left.\mathrm{cm}^{-1}\right)$ the pattern and differences are similar to that of amide I, the peak intensity and position of bands are shifted a little bit due to alteration in protein composition and formation of altered protein in induced group as compared to that of normal control (Figure 11b). The amide II band at about $1550 \mathrm{~cm}^{-1}$ was weak and broad in malignant tissue and was strong and sharp in normal tissue, the NDEA+SIB-50 group also shows the similar peak arrangements as that of observed in normal groups. Further, the Amide A (3200-3300 $\mathrm{cm}^{-1}$ ) band arises due to $\mathrm{N}-\mathrm{H}$ stretching but is also contributed by $\mathrm{O}-\mathrm{H}$ stretching and both vibrations represents secondary structure of water soluble proteins [52]. The peak at $3290 \mathrm{~cm}^{-1}$ corresponds to the amide $\mathrm{A}$ that can generally be associated with $\mathrm{N}-\mathrm{H}$ stretching of protein with negligible contribution from $\mathrm{O}-\mathrm{H}$ stretching of intramolecular hydrogen bonding, since unbound water was removed from the system. Lastly in the amide $B$ the peak at $3078 \mathrm{~cm}^{-1}$ is due to $\mathrm{N}-\mathrm{H}$ stretching proteins of amide B proteins [37].

The sharp bands of amide I and amide II bands at 1650-1655 $\mathrm{cm}^{-1}$ and $1540-1545 \mathrm{~cm}^{-1}$ respectively are mainly used to indicate the relative concentration of the protein of biological tissues as these bands represents the amide groups of protein. The band at 1401 and 1452 arises mainly from symmetrical and asymmetrical $\mathrm{CH}_{3}$ bending modes, respectively of the methyl group of protein [53]. But a broad band is formed in this region (1401-1460 $\mathrm{cm}^{-1}$ ) due to contributions from other bands by different other cellular components like nucleic acids and carbohydrates etc.. The intensity of these bands are higher in normal (Figure 11a) and NDEA+SIB-50 (Figure 11d) treated group than that of malignant tissue (Figure 11b). A significant variation in peak intensity in all the peaks and bands viz. 1260-1290, 1401, 1452, $1540-1545,1650-1655 \mathrm{~cm}^{-1}$ are observed in the malignant tissue sample. The parameter differs greatly among all treatment group samples on the basis of protein components. Lipid form the major component of cell walls keeping biological media organized in their necessary compartments. In cancer, a very common stage of disease development is called metastasis, which is the complete separation of cancer affected cells, which invade other organs of the body. The main reason for irregular separation of the cells and their easy destruction relates to the quality of their lipid walls, so lipid also plays an important role [54]. The triglycerides contains lots of methyl, methylene and carbonyl, so the different of Fourier transform infrared spectroscopic spectra in normal and malignant tissue at those area were caused by the different contents of lipid substances in the tissue. In the frequency range $3400-2800 \mathrm{~cm}^{-1}$ known as fatty acid region with specific bands at 3300, 3010, 2958, 2925 and $2854 \mathrm{~cm}^{-1}$ corresponding to the stretching mode of $\mathrm{OH}$ and/ or $\mathrm{N}-\mathrm{H}, \mathrm{H}-\mathrm{C}=\mathrm{C}-\mathrm{H}$, asymmetrical $\mathrm{CH}_{3}$ and both asymmetrical and symmetrical $\mathrm{CH}_{2}$ vibrations respectively changes were observed in this fatty acid region while using malignant samples. The band observed at $2920-2925 \mathrm{~cm}^{-1}$ and $2853-2855 \mathrm{~cm}^{-1}$ are due to asymmetric and symmetric stretching modes of the methylene chain in the membrane lipid respectively [51]. The weak band near $3010 / 3007 \mathrm{~cm}^{-1}$ in the normal control animal was assigned to the vibration of $=\mathrm{CH}$ groups of olefiic bands or unsaturated fatty acids which disappeared in NDEA induced animal tissue sample. A slight shift in the band at $1310 \mathrm{~cm}^{-1}$ was observed in malignant tissue as compared with normal tissue sample. The peak intensities of the band at $2853 \mathrm{~cm}^{-1}$ is higher in normal control group than that of malignant group sample. In malignant tissue sample the intensity of band at $2925 \mathrm{~cm}^{-1}$ was slightly enhanced but with a sharp peak. Taken together, it represents an increase in fatty acid content and/or acryl chain length. The band centered at $1738 \mathrm{~cm}^{-1}$ which was mainly assigned to $>\mathrm{C}=\mathrm{O}$ ester stretching vibration in phospholipids. An increase in intensity was observed indicating the accumulation of lipid in the NDEA induced group but band is submerged with the peak of amide band due to broadening of the amide bands and increased intensity. Moreover, the intense bands observed at $1466 \mathrm{~cm}^{-1}$ which are due to the $\mathrm{CH}_{2}$ asymmetrical bending vibration and $\mathrm{CH}_{3}$ symmetrical bending of the lipid. The band intensity was observed to be increased indicating increases in content of fatty acid chains. Further, the band at $1170 \mathrm{~cm}^{-1}$ and $1060 \mathrm{~cm}^{-1}$ which arises due in part of the ester $\mathrm{C}-\mathrm{O}-\mathrm{C}$ asymmetric and symmetric stretching vibrations in phospholipids and cholesterol esters respectively are increased for the malignant tissue and absent in the treatment group of animal tissues, which supports the biochemical finding of our experiment [49]. Major absorption in the spectra of lipid in the control tissue arises from $\mathrm{C}-\mathrm{C}$ stretching $\left(1117 \mathrm{~cm}^{-1}\right)$ and skeletal $\mathrm{C}-\mathrm{C}$ stretching $\left(1065 \mathrm{~cm}^{-1}\right)$ of lipids [53]. DNA and RNA also play important role in relation to protein structures as they carry information that determines protein structure. the main spectral features of nucleic acids in the infrared region are in plane double bond vibrations of the bases, and asymmetric and symmetric phosphate stretching located at $1750-1600 \mathrm{~cm}^{-1}, 1230 \mathrm{~cm}^{-1}$ and 1100 $\mathrm{cm}^{-1}$, respectively. It is also noticeable that the intensity ratio of the signal located at $1055 \mathrm{~cm}^{-1}$ is the most significant difference between DNA and RNA [54]. In NDEA treated tissue sample, nucleic acids gives rise to a medium intensity peak at $1426 \mathrm{~cm}^{-1}$ and a band near $666 \mathrm{~cm}^{-1}$ which are respectively due to the rings breathing modes of DNA bases (alanine, guanine) and ring breathing modes of DNA bases (guanine and thymine) [55]. In malignant tissue the peak at $1220 \mathrm{~cm}^{-1}$ is greater than that of at $1240 \mathrm{~cm}^{-1}$ of the $\mathrm{PO}_{2}$ group in phosphodiester group of nucleic acids. In liver cancer many $\mathrm{PO}_{2}$ groups of nucleic acids are hydrogen bonded, in contrast to those of normal liver tissue. The band at $1082 \mathrm{~cm}^{-1}$ is mainly due to symmetrical phosphates $\left(\mathrm{PO}_{2}\right)$ stretching mode [47]. This band is found higher and stronger in malignant tissue than that in normal tissue. Changes were noted in treated groups and are noticeable which prove the bio-structural changes due to malignancy and are brought back to almost normal levels after the Silibinin treatment. Our work defines, SIB could be a useful and novel therapeutic drug to control HCC. Further preclinical and clinical trials are warranted to research the full potential of this important natural flavonoid analogue.

\section{Acknowledgements}

Authors need to express thanks to All India Council of Technical Education for the Fellowship support. Authors are greatly acknowledge the authorities of Birla Institute of Technology for the necessary facilities provided for the smooth running of the project and also, thankful to Department of Health, Medical Education and Family welfare, Government of Jharkhand for the continuous encouragement and support towards biomedical research.

\section{We declare no conflict of interest.}

\section{Author contributions}

SP Pattanayak and A Kumar performed the majority of the experiments. 
Citation: Kumar A, Sunita P, Pattanayak SP (2015) Silibinin Inhibits the Hepatocellular Carcinoma in NDEA-Induced Rodent Carcinogenesis Model: An Evaluation through Biochemical and Bio-Structural Parameters. J Cancer Sci Ther 7: 207-216. doi:10.4172/1948-5956.1000352

P Sunita performed some histological staining procedure. P Sunita and SP Pattanayak designed the experiments and wrote the manuscript. All authors discussed the results and commented on the manuscript.

\section{References}

1. Qian Y, Ling CQ (2004) Preventive effect of Ganfujian granule on experimental hepatocarcinoma in rats. World J Gastro 10: 755-757.

2. Parkin DM, Bray F, Ferlay J, Pisani P (2002) Global cancer statistics. CA Can J Clin 55: 74-108.

3. Farazi1 PA, DePinho RA (2006) Hepatocellular carcinoma pathogenesis: from genes to environment. Nat Rev Can 6: 674-687.

4. Brown JL (1999) N-Nitrosamines. Occup Med 14: 839-848.

5. Yadav AS, Bhatnagar D (2007) Chemopreventive effect of Star anise in $\mathrm{N}$-nitrosodiethylamine initiated and phenobarbital promoted hepatocarcinogenesis. Chem Biol Interact 169: 207-214.

6. Sengupta A, Ghosh S, Das S (2004) Modulatory influence of garlic and tomato on cyclooxygenase-2 activity, cell proliferation and apoptosis during azoxymethane induced colon carcinogenesis in rat. Can Lett 208: 127-136.

7. Deml E, Schwarz LR, Oesterle D (1993) Initiation of enzyme-altered foci by the synthetic steroid cyproterone acetate in rat liver foci bioassay. Carcinogenesis 14: 1229-1231.

8. Pound AW, Lawtson TA, Horn L (1973) Increased carcinogenic action of dimethylnitrosamine after prior administration of carbon tetrachloride. $\mathrm{Br} \mathrm{J}$ Expt Path 27: 451-459.

9. Harborne JB, Williams CA (2000) Advances in flavonoid research since 1992 Phytochem 55: 481-504.

10. Ramasamy K, Agarwal V (2008) Multitargated therapy of cancer by Silymarin Can Lett 269: 352-362.

11. Chen C, Huang T, Wong C, Hong C, Tsai Y, et al. (2009) Synergistic anti-cancer effect of baicalein and silymarin on human hepatoma HepG2 Cells. Food Chem Tox 47: 638-644.

12. Hoofnagle JH (2005) Milk thistle and chronic liver disease. Hepato 42: 4

13. Kaur M, Agarwal R (2007) Silymarin and epithelial cancer chemoprevention: How close we are to bedside? Tox App Pharm 224: 350-359.

14. Narayana KR, Reddy MS, Chaluvadi MR, Krishna DR (2001) Bioflavonoids classification, pharmacological, biochemical effects and therapeutical potential. Ind J Pharm 33: 2-16.

15. Negi AS, Kumar JK, Luqman S, Shanker K, Gupta MM, et al. (2008) Recent advances in plant hepatoprotectives: a chemical and biological profile of some important leads. Med Res Rev 28 : 746-772.

16. Cheung CW, Vesey DA, Nicol DL, Johnson DW (2007) Silibinin inhibits renal cell carcinoma via mechanisms that are independent of insulin-like growth factor-binding protein 3. BJU Int 99: 454-460.

17. Zhang S, Yang Y, Liang Z, Duan W, Yang J, et al. (2013) Silybin-mediated inhibition of Notch signaling exerts antitumor activity in human hepatocellular carcinoma cells. PLoS One 8: e83699.

18. Bousserouel S, Bour G, Kauntz H, Gossé F, Marescaux J, et al. (2012) Silibinin inhibits tumor growth in a murine orthotopic hepatocarcinoma model and activates the TRAIL apoptotic signaling pathway. Anticancer Res 32: 2455-2462.

19. King J (1965) The alanine transaminase and aspartate transaminase. In: Van D (ed) Practical clinical enzymology. Nostrand, London p. 121-138.

20. Pattanayak SP, Mazumder PM (2010) Therapeutic potential of Dendrophthoe falcata (L.f.) Ettingsh on 7,12-dimethyl benz(a)anthracene-induced mammary tumorigenesis in female rats: effect on antioxidant system, lipid peroxidation and hepatic marker enzymes. Comp Clin Pathol 20: 381-392.

21. Belfield A, Goldberg D (1971) Colorimetric determination of alkaline phosphatase activity. J Clin Path 12: 561-566.

22. Szasz G (1969) Kinetic determination of serum gamma glutamyle transferase Clin Chem 15: 124-126.

23. Ohkawa H, Ohishi N, Yagi K (1979) Assay of lipid peroxides in animal tissues by thiobarbituric acid reaction. Anal Biochem 95: 351-358.
24. Lowry OH, Rosebrough NJ, Farr AL, Randall RJ (1951) Protein measurement with the Folin-phenol reagent. J Biol Chem 193: 265-275.

25. Flohe L, Otting F (1984) Superoxide dismutase assays. Meth Enzymol 105: 93 26. Sinha AK (1972) Colorimetric assay of catalase. Anal Biochem 47: 389-394.

27. Rotruck JT, Pope AL, Ganther HE, Swanson AB, Hafeman DG, et al. (1973) Selenium: biochemical role as a component of glutathione peroxidase. Science 179: $588-590$

28. Habig WH, Pabst MJ, Jakoby WB (1974) Glutathione-S-transferase: the firs enzymatic step in mercapturic acid formation. J Biol Chem 249: 7130-7139.

29. Folch J, Less M, Stanely GHS (1951) A simple method for the isolation and purification of total lipids from animal tissues. J Biol Chem 226: 504-509.

30. Rice EW (1970) Triglycerides in serum. In: Roderick P, Mac-Donald CH (eds) Standard methods of clinical chemistry, 6th edn. Academic Press, New York pp 215-222.

31. Van Handle E (1961) Modification of the micro determination of triglycerides. Clin Chem 7:249-251.

32. Parkeh AC, Jung DH (1970) Cholesterol determination with ferric chloride uranium acetate and sulphuric acid-ferrous sulphate reagents. Anal Chem 42 1423-1427.

33. Sujatha V, Sachdanandam P (1997) Effect of Semicarpus anacardium Linn nut extract on experimental mammary carcinoma in Spague- Dawley rats with reference to tumor marker enzymes. Pharm Pharmacol Commun 6: 375-379.

34. Nandave M, Ojha S K, Kaur R (2005) Changes in levels of serum glycoproteins in major depressive disorders. Indian J Clin Biochem 20: 154-157.

35. Pattanayak S P, Sunita P, Mitra Mazumder P (2014) Restorative effect of Dendrophthoe falcata (L.f.) Ettingsh on lipids, lipoproteins, and lipidmetabolizing enzymes in DMBA-induced mammary gland carcinogenesis in Wistar female rats. Comp Clin Pathol 23:1013-1022.

36. Rosmorduc O, Wendum D, Corpechot C, Galy B, Sebbagh N, et al. (1999) Hepatocellular hypoxia-induced vascular endothelial growth factor expression and angiogenesis in experimental biliary cirrhosis. Am J Pathol 155: 1065-1073.

37. Palaniappan PR, Vijaysundaram V, Prabu SM (2011) A study of the subchronic effects of Arsenic exposure on the liver tissue of Lebeo Rohita using Fourier transform infrared technique. Environ Toxicol 26: 338-344.

38. Lee SJ, Boyer TD (1993) The effect of hepatic regeneration on the expression of the glutathione-S-transferases. Biochem J 293: 137-142.

39. Singh BN, Singh BR, Sharma BK, Singh HB (2009) Potential Chemoprevention of $\mathrm{N}$-nitrosodiethylamine-induced hepatocarcinogenesis by polyphenolics from Acacia nilotica bark. Chem Biol Int 181: 20-28.

40. Cooper ME, Hardy KJ (1996) Effects of liver transplantation and resection on lipid parameters: a longitudinal study New Zealand. J Surgery 66: 743-746.

41. Weiden S (1958) Serum Hexosamine levels in health and disease. J Clin Patho 11: 177-182.

42. Klaunig JE, Kamendulis LM (2004) The role of oxidative stress in carcinogenesis Ann Rev Pharm Tox 44: 239-267.

43. Sukata T, Uwagawa S, Ozaki K, Sumida K, Kikuchi K, et al. (2004) Alpha(2) Macroglobulin: a novel cytochemical marker characterizing preneoplastic and neoplastic rat liver lesions negative for hitherto established cytochemical markers. Am J Patho 165: 1479-1488.

44. Valderrama B, Ayala M, Vazquez-Duhalt $R$ (2002) Suicide inactivation of peroxidases and the challenge of engineering more robust enzymes. Chem Biol 9: 555-565

45. Sundaresan S, Subramanian S (2003) S-allylcysteine inhibits circulatory lipid peroxides and promotes in $\mathrm{N}$-nitrosodiethylamine induced carcinogenesis. Pol J Pharm 55: 37-42.

46. Dakshayani KB, Subramanian P, Manivasagam T, Essa M, Manoharan $S$ (2005) Melatonin modulates the oxidant-antioxidant imbalance during N-Nitrosodiethylamine induced Hepatocarcinogenesis. J Pharm Sci 8: 316-321.

47. Wong PTT, Wong RK, Caputo TA, Goodwin TA, Rigas B(1991) Infrared spectroscopy of exfoliated human cervical cells: Evidences of extensive structural changes during carcinogenesis. Proc Nat Acad Sci 88: 10988-10992.

48. Melin AM, Perromat A, Deleris G (1999) Pharmacologic application of fourie 
Citation: Kumar A, Sunita P, Pattanayak SP (2015) Silibinin Inhibits the Hepatocellular Carcinoma in NDEA-Induced Rodent Carcinogenesis Model: An Evaluation through Biochemical and Bio-Structural Parameters. J Cancer Sci Ther 7: 207-216. doi:10.4172/1948-5956.1000352

transform IR spectroscopy: In vivo toxicity of carbon tetrachloride on Rat liver. Biopol Biospectro 57: 160-168.

49. Venkataramana GV, Kumar JK, Devi Prasad AG, Karimi P (2010) Fourier transform infrared spectroscopy study on liver of Freshwater Fish Oreochromis Mossambicus. Rom J Biophy 20: 315-322.

50. Damania G, Cavalu S, Miclaus V, Sabau L, Vedeanu N, et al. (2007) EPR and ATR-FTIR investigation of lyophyliaed cytocrome $\mathrm{C}$ at different $\mathrm{pH}$. Rom J Biophy 17: 139-148.

51. Yang Y, Sule-Suso J, Sockalingum GD, Kegelaer G, Manfait M, et al. (2005) Study of tumor cell invasion by Fourier transform infrared microspectroscopy. Biopoly 78: 311-317.
52. Eckel R, Huo H, Guan HW, Hu X, Che X, et al. (2001) Characteristic infrared spectroscopic patterns in the protein bands of human breast cancer tissue. Vib Spectro 27: $165-173$

53. Movasaghi Z, Rehman S, Rehman IU (2008) Fourier transform infrared Spectroscopy of biological tissues. Appl Spectro Rev 43: 134-179.

54. Krishnakumar N, Manoharan S, Palaniappan PLRM, Venkatachalam P, Arun manohar MG (2009) Chemopreventive efficacy of Piperine in 7,12-dimethyl benz[a] anrhracene(DMBA)-induced hamster buccal pouch carcinogenesis: An FT-IR study. Food chem Techno 23: 45-51.

55. Wang JS, Shi JS, Xu YZ, Duan XY, Zhang L, et al. (2003) FT-IR spectroscopic analysis of normal and cancerous tissues of esophagus. World J Gastro 9 : 1897-1899. 